\title{
OBOWIĄZKI INFORMACYJNE PRACODAWCY ZWIĄZANE Z ZAWIERANIEM UMÓW O PRACE PO NOWELIZACJI KODEKSU PRACY
}

\section{UWAGI WPROWADZAJĄCE}

W 2016 r. weszło w życie wiele zmian w przepisach Kodeksu pracy. Do najważniejszych z nich zaliczyć można modyfikację katalogu umów o pracę, zasad wypowiadania kontraktów na czas określony, sposobu limitowania umów terminowych, reguł zawierania umów na okres próbny, czy też zmianę unormowań związanych z uprawnieniami rodzicielskimi. O zmianach tych szeroko rozpisywała się już doktryna prawa pracy ${ }^{1}$.

Niewiele natomiast uwagi poświęcono dotychczas nowym kodeksowym obowiązkom informacyjnym, które zostały na pracodawcę nałożone w drodze wejścia w życie ustawy z 25 czerwca 2015 r. o zmianie ustawy - Kodeks pracy oraz niektórych innych ustaw (Dz. U. 2015, poz. 1220). Również wydawałoby się „kosmetyczna” modyfikacja art. 29 § 2 k.p. przez ustawę z 13 maja 2016 r. o zmianie ustawy - Kodeks pracy (Dz. U. 2016, poz. 910) nie była przedmiotem szerszego zainteresowania przedstawicieli nauki, mimo że zlikwidowała możliwość nadużyć, do jakich dochodziło powszechnie na rynku pracy, zwanych potocznie „syndromem pierwszej dniówki”. Z tych m.in. względów przedmiotem rozważania niniejszego artykułu uczyniona została problematyka nowych obowiązków informacyjnych pracodawcy wynikających ze wspomnianych wyżej nowelizacji. Ich nienależyte wypełnienie może narazić podmiot zatrudniający nawet na odpowiedzialność karnoprawną w postaci grzywny w wysokości do $30000 \mathrm{zl}$.

${ }^{1}$ L. Mitrus, Projekt nowelizacji Kodeksu pracy dotyczqcy umów terminowych, „Monitor Prawa Pracy” 2015, nr 6; J. Stelina, Nowa koncepcja umowy o pracę na czas określony, „Państwo i Prawo” 2015, z. 11; K. Jaśkowski, Nowa umowa o pracę na czas określony, „Praca i Zabezpieczenie Społeczne” 2015, nr 11; A. Ludera-Ruszel, Ocena nowej regulacji umowy o prace na czas okréslony - pozytywny kierunek zmian czy utrzymane status quo?, „Praca i Zabezpieczenie Społeczne” 2016, nr 2; Ł. Pisarczyk, Nowy model zatrudnienia terminowego w prawie pracy? - część 1 i 2, „Monitor Prawa Pracy” 2016, nr 5 i 6; K. Jaśkowski, Zwolnienie pracownika z obowiazku świadczenia pracy, „Praca i Zabezpieczenie Społeczne” 2016, nr 3; K. Kulig, Urlop rodzicielski - analiza problemowa, „Praca i Zabezpieczenie Społeczne” 2016, nr 3; K. Nogańska, Uprawnienia pracowników zwiazane z rodzicielstwem - część 1 i 2, „Inspektor Pracy” 2016, nr 6 i $7-8$. 


\section{OBOWIĄZKI WYNIKAJĄCE Z ART. $25^{1}$ § 5 I 29 § $1^{1}$ K.P.}

Obszerna nowelizacja Kodeksu pracy, która weszła w życie 22 lutego 2016 r., miała na celu m.in. podniesienie efektywności funkcjonowania w praktyce mechanizmu limitowania umów na czas określony. Wymóg zapewnienia takiej efektywności jest konsekwencją implementacji przez Polskę dyrektywy 99/70/WE z 28 czerwca 1999 r., a w szczególności będącego jej załącznikiem porozumienia ramowego z 18 marca $1999 \mathrm{r}$. w sprawie pracy na czas określony, zawartego przez Europejską Unię Konfederacji Przemysłowych i Pracodawców (UNICE), Europejskie Centrum Przedsiębiorstw Publicznych (CEEP) oraz Europejską Konfederację Zwiazków Zawodowych (ETUC). Wspomniana tu unijna regulacja nakłada na państwa członkowskie m.in. obowiązek wdrożenia mechanizmów prawnych zapobiegających nadużywaniu przez pracodawców umów terminowych, z którego to obowiązku Polska przez wiele lat nie wywiązywała się należycie. Stanowisko takie potwierdzają nie tylko badania prowadzone w obszarze rynku pracy ${ }^{2}$, ale także opinia Komisji Europejskiej, według której nasz kraj wadliwie wdrożył w tym zakresie wspomnianą wyżej dyrektywę ${ }^{3}$.

Obecnie, w myśl art. $25^{1} \S 1$ k.p., okres zatrudnienia na podstawie umowy o pracę na czas określony, a także łączny okres zatrudnienia na podstawie umów o pracę na czas określony zawieranych między tymi samymi stronami stosunku pracy, nie może przekraczać 33 miesięcy, a łączna liczba tych umów nie może przekraczać trzech. Mechanizm ten nie znajduje jednak zastosowania do umów o pracę zawartych na czas określony:

1) w celu zastępstwa pracownika w czasie jego usprawiedliwionej nieobecności w pracy,

2) w celu wykonywania pracy o charakterze dorywczym lub sezonowym,

3) w celu wykonywania pracy przez okres kadencji,

4) w przypadku gdy pracodawca wskaże obiektywne przyczyny leżące po jego stronie - jeżeli ich zawarcie w danym przypadku służy zaspokojeniu rzeczywistego okresowego zapotrzebowania i jest niezbędne w tym zakresie w świetle wszystkich okoliczności zawarcia umowy (art. $25^{1} \S 4$ k.p.).

We wskazanych wyżej przypadkach pracodawca ma zatem możliwość nielimitowanego zawierania umów o pracę na czas określony, co może otwierać w praktyce pole do różnego rodzaju nadużyć. Aby zminimalizować ryzyko ich

${ }^{2}$ W latach 2009-2012 (według danych Eurostatu) Polska spośród wszystkich krajów Unii Europejskiej znajdowała się na pierwszym miejscu, jeśli chodzi o stosunek liczby osób zatrudnionych na podstawie umów terminowych względem ogółu zatrudnionych (w wieku 15-64 lat), przekraczając tym samym o prawie $100 \%$ średnią unijną. Szerzej na ten temat zob. M. Rylski, Ochrona pracownika przed nadużywaniem terminowego zatrudnienia, „Praca i Zabezpieczenie Społeczne” 2014, nr 8, s. 2-4.

${ }^{3}$ Stanowisko Komisji Europejskiej nr 2013/4161, będące odpowiedzią na skargę wniesiona w dniu 12.09.2012 r. przez Komisję Krajową NSZZ „Solidarność”, http://www.solidarnosc.org.pl/ stara/uploads/oryginal/1/4/2b5f6_Skarga_calosc.pdf [dostęp: 1.04.2016]. Pełna treść odpowiedzi, jaką Komisja Europejska udzieliła na zarzuty podniesione w skardze przez NSZZ „Solidarność”, jest w posiadaniu autora dzięki uprzejmości władz tegoż związku. 
wystapienia, na podmiot zatrudniający nałożone zostały dwa, niewystępujące dotychczas obowiązki o charakterze informacyjnym. Po pierwsze, pracodawca jest zobligowany wskazać w treści tego typu umów cel ich zawarcia lub okoliczności, w jakich do tego doszło, przez umieszczenie informacji o obiektywnych przyczynach uzasadniających ich zawarcie (art. $29 \S 1^{1}$ k.p.). Po drugie, w przypadku umów z art. $25^{1} \S 4$ pkt 4 k.p. dodatkowo konieczne jest zawiadomienie przez pracodawcę właściwego okręgowego inspektora pracy, w formie pisemnej lub elektronicznej, o zawarciu umowy i obiektywnych przyczynach takiego stanu rzeczy, w terminie 5 dni roboczych od dnia dokonania czynności prawnej (art. $25^{1} \S 5$ k.p.). Przy czym wspomniane wyżej obowiązki informacyjne ciążą na podmiocie zatrudniającym nie ze względu na fakt przekroczenia limitów zatrudnienia terminowego określonych w art. $25^{1} \S 1$ k.p. ${ }^{4}$, lecz ze względu na fakt dokonania czynności prawnej z powołaniem się na obiektywne przyczyny, o których mowa w art. $25^{1} \S 4$ k.p. ${ }^{5}$

Ze wskazanym wyżej mechanizmem ochronnym (informacyjnym) wiąże się jednak wiele wątpliwości, i to nie tylko co do jego praktycznej skuteczności, ale również prawidłowej wykładni.

W pierwszej kolejności wypada zauważyć, że należyte wypełnienie obowiązku z art. $29 \S 1^{1}$ k.p. umożliwia pracodawcy pośrednio właściwe dopełnienie obowiązku wynikającego z art. $25^{1} \S 5 \mathrm{k}$.p. poprzez wysłanie do inspekcji pracy samej umowy o pracę na czas określony (czynność ta bowiem właściwie dokumentuje fakt zawarcia umowy, strony czynności prawnej i obiektywne przyczyny takiego stanu rzeczy, które powinny być wskazane w jej treści; taka optykę potwierdza też przepis art. 15 ust. 2 ustawy nowelizującej, który bieg terminu na zgłoszenie umowy do inspekcji pracy uzależnia od „dnia uzupełnienia umowy o pracę o informacje o przyczynach zawarcia tej umowy”). Pracodawcy nie zawsze jednak będą chcieli ujawniać pełną treść zawartej z pracownikiem umowy o pracę, a gdyby zawierała ona informacje objęte ochrona prywatności pracownika (np. wysokość wynagrodzenia za pracę), takie działanie podmiotu zatrudniającego mogłoby być uznane za nielegalne (inspektorzy mają bowiem prawo wglądu w wynagrodzenia pracowników, ale tylko działając w okolicznościach mających oparcie na ustawie). W praktyce zatem pracodawcy w skierowanym do inspekcji zawiadomieniu powinni ograniczyć się do informacji ściśle określonych w przepisach prawa. Za niewystarczajace należałoby jednak uznać przepisanie treści art. $25^{1} \S 4$ pkt 4 k.p. bez wskazania konkretnych obiektywnych przyczyn leżacych po stronie pracodawcy. Takie postępowanie podmiotu zatrudniającego należałoby traktować na równi z niedopełnieniem obowiązku informacyjnego w ogóle.

Nie ulega wątpliwości, że za wystarczające do należytego wywiązania się z obowiązku określonego w art. $29 \S 1^{1} \mathrm{k}$.p. jest wskazanie przez strony w umowie przyczyn, o których mowa w art. $25^{1} \S 4$ pkt $1-4$ k.p. (w tym ostatnim przypadku oczywiście odpowiednio dookreślonych względem zwrotu ustawowego).

${ }^{4}$ Tak jednak L. Mitrus, Projekt..., s. 289; I. Jaroszewska-Ignatowska, w: K. Walczak (red.), Kodeks pracy. Komentarz, Legalis/el. 2016.

5 Tak słusznie Ł. Pisarczyk, Nowy model..., cz. 1, s. 181. Zob. też wyrok TSUE z 24 czerwca 2010 r. w sprawie Sorge przeciwko Poste Italiane SpA (EU:C:2010:369). 
Wątpliwości rodzi natomiast to, czy zawiadomienie inspekcji pracy, o którym mowa w art. $25^{1} \S 5$ k.p., musi uwzględniać także pozostałe przesłanki zastosowania nielimitowanego zatrudnienia, tj. istnienie rzeczywistego okresowego zapotrzebowania na pracę danego pracownika i niezbędność wykorzystania terminowego zatrudnienia $\mathrm{w}$ świetle wszystkich okoliczności zawarcia umowy. Z logiki omawianego tu mechanizmu ochronnego wynikałoby, że spełniać on będzie efektywnie swoją rolę jedynie wtedy, gdy inspekcja pracy będzie mogła ocenić (skontrolować) dopuszczalność zastosowania umowy z art. $25^{1}$ $\S 4$ pkt 4 k.p. na etapie zawiadomienia w pełnej rozciąłości, a nie tylko w zakresie jednej przesłanki. Niemniej brak nałożenia na pracodawcę podobnego obowiązku informacyjnego w przypadku umów wskazanych w art. $25^{1} \S 4$ pkt 1-3 k.p., co do których te dodatkowe przesłanki znajdują w pełni zastosowanie, przeczy takiej logice. Ostatecznie należy zatem uznać, że pracodawca nie musi w zawiadomieniu skierowanym do inspekcji pracy w jakikolwiek sposób odnosić się do istnienia po jego stronie rzeczywistego okresowego zapotrzebowania na pracę danego pracownika i wykazywać niezbędności zastosowania terminowego zatrudnienia, choć niekiedy z samej podanej przez pracodawcę przyczyny zawarcia umowy będzie można, przynajmniej częściowo, wnioskować o powyższych okolicznościach. Najczęściej jednak inspekcja pracy w celu zweryfikowania owych okoliczności zmuszona będzie do podjęcia dodatkowych czynności kontrolnych, do czego oczywiście w świetle nowego stanu prawnego jest w pełni uprawniona.

W razie gdyby treść umowy o pracę w zakresie, o którym mowa w art. 29 $\S 1^{1}$ k.p., na moment dokonywania czynności prawnej nie odpowiadała rzeczywistości, umowę taką należałoby traktować jak zawartą na czas określony i podlegajaccą limitowaniu ${ }^{6}$. Konstatacja ta nie budzi wątpliwości, gdy w umowie o pracę wskazano obiektywną przyczynę w rzeczywistości nie występująca. Kontrowersje mogą się natomiast pojawić, gdy przyczyna taka faktycznie istnieje, ale nie została przez strony wskazana w treści umowy o pracę (1), bądź została co prawda wskazana, ale już po zawarciu umowy o pracę (2). W obydwu przypadkach wątpliwości biora się z faktu, że obowiązek wskazany w powołanym wyżej przepisie ma charakter jedynie informacyjny (wtórny) i jego nienależyte dopełnienie nie wpływa na istnienie po stronie pracodawcy „obiektywnych przyczyn”. Tym samym przyjmowanie nieopartej wyraźnie na przepisach sankcji w postaci wliczania do limitu zatrudnienia terminowego umowy na czas określony uzasadnionej obiektywnymi powodami tylko ze względu na fakt nieujawnienia tychże wobec pracownika (w ogóle lub w pierwszej chwili) może budzić zastrzeżenia.

Z drugiej strony trudno też przyjąć, że wywiązanie się przez pracodawcę $\mathrm{z}$ omawianego tu obowiązku nie jest ograniczone żadnym terminem, a jego nieprawidłowa realizacja nie jest obłożona żadną sankcją zważywszy na fakt różnicowania przez ustawodawcę sytuacji pracownika w zależności od tego, czy zawarcie umowy na czas określony jest, czy też nie jest obiektywnie uzasadnione.

${ }^{6}$ Tak ibidem, s. 180-181. Odmiennie J. Stelina, Nowa..., s. 49-50. 
Nie bez znaczenia jest również to, że pracownik na moment zawierania umowy o pracę nie ma w zasadzie możliwości sprawdzenia, czy po stronie pracodawcy istnieja „obiektywne przyczyny”, gdyż to właśnie pracodawca posiada o nich wiedzę, którą z tego względu powinien podzielić się z pracownikiem najpóźniej w dniu zawarcia umowy. Wymaga tego elementarna uczciwość wobec pracownika (drugiej strony kontraktu), który decyzję o podpisaniu umowy lub warunkach jej realizacji może uzależniać od tak kluczowej kwestii, jak rodzaj reżimu prawnego, zgodnie z którym terminowe zatrudnienie będzie realizowane.

Z powyższych względów należy przyjąć, że pracodawca, który w momencie zawarcia umowy o pracę nie ujawnia pracownikowi okoliczności określonych w art. $29 \S 1^{1}$ k.p., musi liczyć się z tym, że umowa taka, choćby obiektywnie uzasadniona, podlegać będzie limitowaniu jak „zwykła” umowa na czas określony ${ }^{7}$. Późniejsze powoływanie się przez pracodawcę na istnienie „obiektywnych przyczyn" niczego w tym zakresie nie zmienia, choćby ostatecznie (oczywiście za zgoda pracownika) zostały one wpisane do umowy o pracę zgodnie z art. 29 $\S 1^{1}$ k.p. Przeciwko dopuszczalności późniejszej zmiany umowy o pracę na czas określony z akauzalnej na kauzalną w drodze modyfikacji istniejącego między stronami kontraktu przemawia m.in. fakt, że art. $25^{1} \S 5$ k.p. wiąże pracodawczy obowiązek informacyjny wobec inspekcji pracy, jak również termin na jego dopełnienie, wyłącznie z okolicznością zawarcia umowy o pracę. Możliwe jest natomiast przyjęcie interpretacji, że późniejsze uzupełnienie umowy na czas określony o informacje, o których mowa w art. $29 \S 1^{1}$ k.p. powinno być traktowane jak zawarcie nowej umowy o pracę (ze wszystkimi tego konsekwencjami).

$\mathrm{Na}$ marginesie należy jednak podkreślić, że wskazana na początku poprzedniego akapitu sankcja nie dotyczy przypadków, w których zastosowanie umowy na czas określony jest nakazane przepisami prawa ${ }^{8}$. Dla własnego bezpieczeństwa pracodawcy powinni natomiast dopełnić obowiązku z art. 29 $\S 1^{1}$ k.p., gdy zawierają umowę na czas określony opartą na przepisach szczególnych, które dopuszczają możliwość jej zastosowania, ale tego nie nakazują. W tym bowiem przypadku możliwe jest przyjęcie poglądu, iż powinno się per analogiam stosować wskazane wyżej unormowanie, które znajduje przecież zastosowanie także w okolicznościach, gdy wykorzystanie kontraktu terminowego zostało przez ustawodawcę wyraźnie dopuszczone w przepisach prawa (art. $25^{1} \S 4$ pkt 1-3 k.p.).

Dotychczas była mowa jedynie o konsekwencjach braku ujawnienia przez pracodawcę „obiektywnych okoliczności” przy zawarciu kontraktu, a także konsekwencjach ich ujawnienia już po zawarciu umowy o pracę. Odrębną natomiast kwestia jest forma dopełnienia wspomnianego obowiazku.

Wychodząc z założenia, że prawidłowe zastosowanie art. $29 \S 1^{1}$ k.p. ma na celu zagwarantowanie pracownikowi świadomości co do rodzaju umowy na czas określony, jaką zawiera z pracodawca, to wydaje się, że forma realizacji obowiązku informacyjnego ma znaczenie drugorzędne.

7 Tak słusznie Ł. Pisarczyk, Nowy model..., cz. 1, s. 180.

8 Tak w przypadku robót publicznych i prac interwencyjnych SN w wyroku z 28 sierpnia 2013 r., I PK 46/13, Lex nr 1497143; choć stanowisko SN można uznać za kontrowersyjne. 
$\mathrm{Z}$ drugiej jednak strony przepis ten ma niewątpliwie na celu również ułatwienie organom nadzoru nad praca zweryfikowania prawidłowości postępowania pracodawcy $\mathrm{w}$ zakresie przestrzegania przepisów o zatrudnianiu na podstawie umów na czas określony. To z kolei przemawiałoby za formą pisemna, w szczególności, że należy zakładać, iż nie wszyscy pracodawcy będą w każdym przypadku dopełniać powinności, o której mowa w art. $25^{1} \S 5$ k.p. Również z literalnego brzmienia art. $29 \S 1^{1}$ k.p. zdaje się wynikać, że ustanowiony tą regulacja obowiązek może być zrealizowany jedynie w formie pisemnej (,,przez zamieszczenie informacji o obiektywnych przyczynach uzasadniających zawarcie takiej umowy"). Wniosek taki znajduje także oparcie w brzmieniu przepisu art. 15 ust. 2 ustawy wprowadzającej komentowana nowelizację, gdzie mowa jest o konieczności „uzupełnienia umowy o pracę” o podane wyżej informacje. Językowy kształt tych przepisów może prowadzić do konkluzji, że zawarcie nielimitowanej umowy na czas określony w inny sposób niż w formie pisemnej nie jest w ogóle możliwe, a w konsekwencji forma pisemna zastrzeżona została także dla informacji o „obiektywnych okolicznościach”. Warto jednak zauważyć, że przepisy Kodeksu pracy nie wymagaja pisemnej formy od jakiejkolwiek umowy o pracę, a jedynie pisemnego potwierdzenia przez pracodawcę ustaleń co do stron umowy, jej rodzaju oraz warunków. Takie jednostronne potwierdzenie powinno oczywiście zawierać również wskazanie informacji, o których mowa w art. $29 \S 1^{1} \mathrm{k}$.p., ale ich podanie pracownikowi w ten sposób nie spełnia wymogu „zamieszczenia w umowie” czy też „,uzupełnienia umowy”.

Ostatecznie należy stanąć na stanowisku, że strony moga zawierać nielimitowane umowy na czas określony również w innej formie niż pisemna, o ile pracodawca poinformował pracownika o okolicznościach, o których mowa w art. $29 \S 1^{1}$ k.p., a pracownik, mimo świadomości wystapienia tych okoliczności, wyraził zgodę na nawiązanie stosunku pracy. Wspomniane poinformowanie pracownika może nastapić także w formie innej niż pisemna. Stanowisko takie w najwyższym stopniu szanuje zasadę swobody umów, a jednocześnie uwzględnia interesy słabszej strony stosunku pracy.

Niezależnie od powyższego pracodawca, już po zawarciu umowy o pracę, powinien potwierdzić pracownikowi na piśmie wystapienie „obiektywnych okoliczności”, co wchodzi w zakres regulacji art. $29 \S 2$ k.p. Brak takiego potwierdzenia, podobnie jak brak zawarcia informacji o „obiektywnych okolicznościach" w pisemnej umowie o pracę, nie wyłącza możliwości dowodzenia przez pracodawcę, iż pracownik o istnieniu tych okoliczności wiedział (nawet ze źródeł innych niż pracodawca) oraz - co najważniejsze - miał świadomość, że ze względu na ich występowanie zawiera z pracodawcą umowę o pracę niepodlegająca limitowaniu. Dowód taki będzie jednak w praktyce bardzo trudny do przeprowadzenia, a dodatkowo nie zwolni pracodawcy z sankcji za niewykonanie obowiązu informacyjnego, o którym mowa w art. $29 \S 2$ k.p. Może natomiast zapobiec zaliczeniu istniejącej pomiędzy stronami umowy o pracę na czas określony do limitu, o którym mowa w art. $25^{1} \S 1$ k.p.

Zawarte w umowie informacje, o których wspomina art. $29 \S 1^{1}$ k.p. sa oświadczeniem wiedzy pracodawcy (a nie woli stron), pracownik zaś, który jedynie w bierny sposób przyjmuje je do wiadomości, ma zawsze możliwość ich 
podważenia. Ciężar udowodnienia obiektywnych powodów uzasadniających zastosowanie nielimitowanego zatrudnienia, jak również innych związanych z tym faktem przesłanek będzie w pierwszej kolejności spoczywał zasadniczo na pracodawcy ${ }^{9}$.

W myśl art. $25^{1} \S 5$ k.p. pracodawca jest zobligowany powiadomić o zawarciu umowy o pracę wskazanej w art. $25^{1} \S 4$ pkt 4 k.p. (wraz z podaniem przyczyn jej zawarcia) „właściwego inspektora pracy”. Właściwego terytorialnie, ze względu na miejsce, w którym znajduje się pracodawca zawierający z pracownikiem umowę objętą obowiązkiem zgłoszenia. Jeśli zatem pracodawcą byłaby w danym przypadku centrala spółki, to choćby pracownik pracował faktycznie w jednym $\mathrm{z}$ jej oddziałów - właściwym inspektorem pracy byłby ten pracujący w okręgowym inspektoracie, którego właściwością terytorialną objęta byłaby centrala spółki.

Zawiadomienie powinno być dokonane na piśmie albo $\mathrm{w}$ formie elektronicznej, np. przez przesłanie wiadomości e-mail bezpośrednio na adres poczty internetowej okręgowego inspektoratu pracy lub za pośrednictwem formularza dostępnego na stronie inspekcji (wiadomość nie musi być opatrzona tzw. podpisem elektronicznym).

Brak należytego dopełnienia przez pracodawcę obowiązku informacyjnego z art. $25^{1} \S 5$ k.p. obłożony jest surową sankcją o charakterze prawnokarnym (art. 281 pkt 1a k.p.). Sankcja ta może zostać uruchomiona nie tylko ze względu na brak zawiadomienia inspektora pracy o zawarciu umowy wskazanej w art. $25^{1} \S 4$ pkt 4 k.p., ale również w razie dokonania takiego zawiadomienia po terminie. Termin ten, jak już zostało wspomniane, wynosi 5 dni roboczych i biegnie od dnia następującego po dniu, w którym nastapiło zawarcie umowy o pracę (nie zaś nawiązanie stosunku pracy). Dniami roboczymi są tutaj dni od poniedziałku do piątku ${ }^{10} \mathrm{z}$ wyłączeniem tych, w które przypada ustawowo wolne święto.

Wydaje się, że wspomniana wyżej sankcja jest wystarczająca i nie ma potrzeby przyjmować, że niezgłoszona do inspekcji umowa bądź zgłoszona wadliwie albo po terminie powinna być traktowana jak umowa na czas określony podlegająca limitowaniu.

Na koniec należy raz jeszcze wspomnieć, że inspektor pracy ma ograniczone możliwości ustalenia legalności wykorzystania przez pracodawcę nielimitowanego zatrudnienia terminowego $\mathrm{w}$ oparciu o samo zgłoszenie i podane $\mathrm{w}$ nim powody. Aby sprawdzić prawidłowość dokonanej przez pracodawcę czynności prawnej, zmuszony będzie zatem z reguły podjać dodatkowe czynności kontrolne, w trakcie których może się okazać, że obiektywny powód nie istnieje lub nie uzasadnia skorzystania przez pracodawcę $\mathrm{z}$ art. $25^{1} \S 4 \mathrm{k}$.p. Aby jednak doprowadzić do zmiany kwalifikacji umowy o pracę, inspektor będzie z reguły zmuszony wystosować pozew o ustalenie istnienia stosunku pracy, chyba że strony zgodzą się na dobrowolną modyfikację łączącego ich kontraktu. Wskazany tu mechanizm kontrolny nie wydaje się zatem zbyt efektywny, a z pewnością nie prowadzi do szybkiego zakończenia ewentualnych patologii na rynku pracy.

\footnotetext{
${ }^{9}$ K. Jaśkowski, Nowa umowa..., s. 6.

10 Zob. uchwałę składu 7 sędziów NSA z 15 czerwca 2011 r., I OPS 1/11, Lex nr 818666.
} 


\section{OBOWIĄZKI WYNIKAJĄCE Z ART. 29 § $2,104^{3}$ § 2 I $200^{1}$ § 5 K.P.}

Z dniem 1 września 2016 r. modyfikacji uległy istniejące już dawniej regulacje dotyczące potwierdzania przez pracodawcę na piśmie warunków zatrudnienia $\mathrm{w}$ razie nawiązania stosunku pracy $\mathrm{w}$ formie innej niż pisemna (art. $29 \S 2$ k.p.), a także zapoznania pracownika z treścia regulaminu pracy (104 ${ }^{3}$ $\S 2$ k.p.) oraz młodocianego $\mathrm{z}$ wykazem prac lekkich (art. $200^{1} \S 5$ k.p.). Przy czym zmiana brzmienia dwóch ostatnich unormowań nie wydaje się wnosić do systemu prawnego nowej jakości. Moment wykonania przez pracodawcę obowiązu informacyjnego określonego w tych przepisach, mimo zmiany ich formuły słownej, w istocie się nie zmienił. Nadal pracodawca nie może dopuścić pracownika do pracy, a pracownik rozpocząc wykonywania pracy, bez zapoznania się z regulaminem pracy, a w przypadku młodocianego także wykazem prac lekkich. Wspomniana tu nowelizacja miała zatem w tym zakresie charakter porządkujący (ujednolicajacy) terminologię, jaką posługuje się ustawodawca w Kodeksie pracy.

Całkowicie odmiennie należy natomiast spojrzeć na nowelizację przepisu art. 29 § 2 k.p., która doprowadziła do zmiany momentu, w jakim pracodawca musi wywiązać się ze wskazanego w nim obowiązku informacyjnego. Wcześniej było to możliwe najpóźniej „w dniu rozpoczęcia pracy przez pracownika”, obecnie zaś ma to nastapić „przed dopuszczeniem pracownika do pracy”. Ta wydawałoby się niewielka zmiana brzmienia przepisu ma kolosalne znaczenie dla praktyki obrotu gospodarczego i wydaje się, że likwiduje, jak zostało już wcześniej wspomniane, powszechne dotychczas zjawisko zwane „syndromem pierwszej dniówki”. Jego istotą było długotrwałe zatrudnianie pracowników bez pisemnej umowy o pracę i bez zgłoszenia ich do ubezpieczenia społecznego, przy jednoczesnym niewywiąywaniu się przez pracodawcę z obowiązku, o którym mowa w art. $29 \S 2$ k.p. Pracodawcy postępujacy w opisany wyżej sposób byli dotychczas w praktyce w zasadzie bezkarni, choć teoretycznie groziła im nawet odpowiedzialność o charakterze karnoprawnym (art. 281 k.p.). W razie bowiem kontroli organów nadzoru nad praca (np. inspekcji pracy) deklarowali oni, że wspomniani wyżej pracownicy sa pierwszy dzień w pracy, służby kadrowe zaś właśnie generuja dla nich odpowiednie dokumenty, które z pewnością otrzymają przed zakończeniem pierwszej dniówki roboczej (dawne brzmienie przepisu dozwalało na takie tłumaczenia). Jeśli do tego dołożymy fakt, że pracodawca na zgłoszenie pracownika do ubezpieczenia społecznego ma 7 dni od momentu nawiązania stosunku pracy, to nie wydaje się dziwne, że w niektórych sytuacjach osoby faktycznie zatrudnione przez wiele miesięcy wykonywały pracę bez jakiejkolwiek osłony socjalnej.

Oczywiście można domniemywać, że opisana wyżej sytuacja nie mogłaby w dłuższej perspektywie czasu skutecznie funkcjonować w obrocie gospodarczym, gdyby nie współudział samych pracowników. Jak wynika z informacji pozyskanych przez piszącego te słowa bezpośrednio od inspektorów pracy, pracownicy podczas przesłuchiwania $\mathrm{w}$ trakcie czynności kontrolnych potwierdzali z reguły wersję pracodawcy, mając zapewne świadomość, iż w in- 
nym przypadku mogą mieć także problemy prawne (np. ze względu na brak wykazywania swoich dotychczasowych zarobków u pracodawcy przed organami podatkowymi).

Z pomoca stronom stosunku pracy przyszedł ustawodawca. Aktualnie pracodawca chcący zawrzeć z pracownikiem umowę o pracę $\mathrm{w}$ innej formie niż pisemna zobligowany jest do potwierdzenia na piśmie ustaleń co do stron umowy, rodzaju umowy oraz jej warunków jeszcze przed dopuszczeniem pracownika do pracy. Potwierdzenie, o którym mowa wyżej, jest jednostronnym oświadczeniem wiedzy i ma znaczenie przede wszystkim dowodowe. Brak dopełnienia przez pracodawcę tego obowiązku nie wpływa na ważność nawiązanego już stosunku pracy, lecz pociaga za sobą sankcję o charakterze karnoprawnym (art. 281 k.p.). Zakres owego potwierdzenia wyznacza art. 29 § 1 k.p., toteż przez pojęcie warunków umowy należy rozumieć rodzaj pracy, miejsce jej wykonywania, wynagrodzenie odpowiadające rodzajowi pracy ze wskazaniem jego składników, wymiar czasu pracy oraz termin jej rozpoczęcia, a także ewentualnie dodatkowe elementy uzgodnione między stronami. W przypadku umowy na czas określony niepodlegającej limitowaniu ze względu na szczególne okoliczności, o których mowa w art. $25^{1} \S 4$ k.p., potwierdzenie powinno zawierać także informacje, o których mowa w art. $29 \S 1^{1} \mathrm{k} . p$.

Na zakończenie warto zauważyć, że obowiązek potwierdzenia na piśmie warunków zatrudnienia jeszcze przed dopuszczeniem pracownika do pracy może być dla pracodawcy niekiedy niemożliwy do wypełnienia. Z przypadkiem takim mamy do czynienia, gdy terminowy stosunek pracy nawiąże się w sposób dorozumiany, w związku i z chwilą dopuszczenia pracownika do pracy, a elementy jego treści wynikać będą nie tyle z wyraźnego i uprzedniego uzgodnienia stron, ile z okoliczności podjęcia pracy (kontekstu sytuacyjnego). W takim przypadku pracodawca nie ma możliwości dopełnienia obowiązów informacyjnych przed dopuszczeniem pracownika do pracy, gdyż omawiane tu potwierdzenie, jak wskazuje sama jego nazwa, poświadcza coś, co zostało uprzednio uzgodnione. Tymczasem we wskazanych wyżej okolicznościach uzgodnienie warunków zatrudnienia przed dopuszczeniem do pracy nie występuje.

Powyższe uwagi obrazować może sytuacja, w której zatrudnionemu uprzednio pracownikowi skończył się okres wypowiedzenia umowy o pracę, lecz mimo jego upływu stawił się on w zakładzie pracy w celu wykonywania pracy, a pracodawca się temu wyraźnie nie sprzeciwił ${ }^{11}$. W takim przypadku może dojść do konkludentnego zawarcia umowy o pracę. I choć z reguły będzie to umowa na czas nieokreślony, to nie jest wykluczone, że ze względu na okoliczności towarzyszące dokonaniu czynności prawnej dojdzie do zawarcia umowy na czas określony $^{12}$.

\footnotetext{
11 Zob. np. wyrok SN z 31 sierpnia 1977 r., I PRN 112/77, Legalis nr 20318.

${ }^{12} \mathrm{Na}$ możliwość taką zwraca uwagę m.in. J. Stelina, w: Kodeks pracy. Komentarz, red. A. Sobczyk, Legalis/el. 2017. Nie wykluczył jej również SN (zob. wyrok z 26 sierpnia 1999 r., I PKN 215/99, OSNAPiUS 2000, nr 24, poz. 890, czy też z 4 listopada 2009 r., I PK 105/09, Legalis nr 218643).
} 


\section{WNIOSKI KOŃCOWE}

Przeprowadzona w niniejszym artykule analiza skłania do wniosku, że ciążące na pracodawcach obowiązi informacyjne, wprowadzone lub zmodyfikowane w drodze ostatnich nowelizacji Kodeksu pracy, mają służyć zapobieżeniu nadużyciom występującym dotychczas powszechnie na rynku pracy. Zmiany $\mathrm{w}$ tym zakresie były potrzebne i oczekiwane, choć sama regulacja prawna może budzić wątpliwości interpretacyjne. Najistotniejsze z nich wiążą się z ustaleniem zakresu zastosowania normy prawnej wyrażonej w przepisie $29 \S 1^{1} \mathrm{k} . \mathrm{p}$., a także sankcji za niedopełnienie wynikającego z niej obowiązku. Z kolei w przypadku art. $29 \S 2$ k.p. kontrowersje mogą zaistnieć w sytuacji, gdy stosunek pracy nawiąże się w sposób dorozumiany, co uniemożliwia w zasadzie należyte wypełnienie przez pracodawcę nałożonych na niego zobowiązań o charakterze informacyjnym. Do tego dochodzi także kwestia efektywności kontroli sprawowanej przez inspektorów pracy nad przestrzeganiem omówionych w niniejszym artykule obowiązków. Wydaje się, że skuteczność narzędzi prawnych, w jakie wyposażono inspekcje pracy, jest $\mathrm{w}$ tym przypadku zdecydowanie niewystarczająca.

dr Mikotaj Rylski

Uniwersytet Szczeciński

mikolaj.rylski@wpiaus.pl

\section{EMPLOYER'S INFORMATION OBLIGATIONS \\ CONNECTED WITH THE CONCLUSION OF AN EMPLOYMENT CONTRACT AFTER THE AMENDMENTS TO THE POLISH LABOUR CODE}

\section{Sum mary}

The article concerns the revised Polish Labour Code (LC) and its amendments which entered into force in 2016 and introduced new or modified the existing disclosure obligations imposed on employers concluding employment contracts with employees. The analysis of the new wording of the provisions leads to the conclusion that proper implementation of employer information obligations can be very embarrassing, and sometimes even impossible to achieve in practice. It is also suggested that supervisory organs may face serious difficulties in effectively controlling fulfilment of these obligations because the legislature has failed to equip the labour inspectorate with effective tools to respond to abuse quickly. Further, it is pointed that some of the provisions and Articles $25^{1} \S 5$ and $29 \S 1^{1} \mathrm{LC}$ in particular create serious doubts of interpretation. These relate, inter alia, to the understanding of 'proper fulfilment of obligations' specified in the regulation, which form it should take, as well as the kind of sanctions for improper satisfaction of the obligation. Finding answers to these questions is one of the purposes of this article. 